Pamiętnik Literacki 2013, 3, s. 87-97
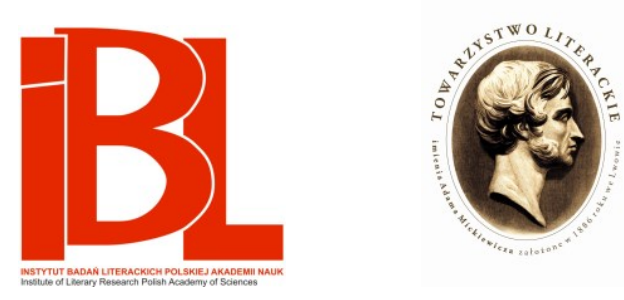

Nosorożec księdza Birkowskiego, czyli symboliczne gry z czytelnikiem barokowego kaznodziei

Jacek Sokolski 


\section{NOSOROŻEC KSIĘDZA BIRKOWSKIEGO, CZYLI SYMBOLICZNE GRY Z CZYTELNIKIEM BAROKOWEGO KAZNODZIEI}

W lutym 1630 zmarł w Nowym Międzybożu na Podolu Stefan Chmielecki, świeżo mianowany wojewoda kijowski, wielki wojownik, którego sława nie wynikała jednak bynajmniej z roli, jaką odegrał w najważniejszych bitwach epoki (spod Cecory uciekł, do obozu pod Chocimiem w ogóle nie dotarł), lecz z sukcesów odniesionych w walkach z czambułami tatarskimi - przez wiele lat dość skutecznie bronił przed nimi południowo-wschodnich granic Rzeczypospolitej ${ }^{1}$. Pochowany został w Barze, a dwa lata później warszawską oficynę królewskiego typografa Jana Rossowskiego opuściła niewielka książeczka zatytułowana Stefan Chmielecki, abo nagrobek Jaśnie Wielmożnego Jego Mości Pana, P. Stephana Chmieleckiego, wojewody kijowskiego, pobożnego, rycerskiego, szczęśliwego, pamięcia pogrzebna wystawiony. Jej autorem był ksiądz Fabian Birkowski, w owym czasie wysoko ceniony nadworny kaznodzieja królewicza Władysława. Nic nie wskazuje na to, by było to kazanie wygłoszone wcześniej na pogrzebie wojewody, w którym to wydarzeniu Birkowski raczej w ogóle nie brał udziału. Najwyraźniej też nie powstało ono na zamówienie rodziny zmarłego, skoro adresatem dedykacji, podpisanej w Warszawie 28 września 1632, nie był żaden z jej członków, lecz przyjaciel królewicza, starosta borysowski Adam Kazanowski (późniejszy marszałek nadworny koronny).

Birkowski, który sam przecież uczestniczył, m.in. jako kaznodzieja obozowy, w zmaganiach pod Chocimiem, wyjątkowo chętnie poświęcał różne swoje kazania wojennym wydarzeniom i ich bohaterom, starając się przy okazji kreować idealny wzorzec „świętego żołnierza”, dzielnego obrońcy ojczyzny i chrześcijaństwa. Takim parenetycznym tekstem jest też niewątpliwie jego kazanie o ,wielkim bohatyrze podolskim" Stefanie Chmieleckim. Wspomnianą dedykację Kazanowskiemu otwiera zresztą wielce charakterystyczna deklaracja, stanowiąca odpowiedź na podstawowe wątpliwości, które już w początkach chrześcijaństwa wiązały się zwykle z profesją żołnierską, później zaś systematycznie powracały w dziełach różnych chrześcijańskich moralistów:

1 Zob. W. D o b row o 1 s k a, Chmielecki Stefan. Hasło w: Polski słownik biograficzny. T. 3. Kraków 1937. 
Wiele takich, zwłaszcza nabożniejszych, którzy rozumieją, iż niepodobna jest żołnierzowi być dobrym i pobożnym człowiekiem. I trzymają się mocno wierszyka onego: Nulla fides pietasque viris qui castra sequuntur. By to prawda była, co mówią, żaden by żołnierz w niebie nie był. A ja, czytając historyje kościelne, coś innego w nich widzę, to jest poczty gromadne świętych żołnierzów, którzy lubo to na wojnie umierali, lubo doma na łożu z wojen zszedszy, prosto śli do nieba i przeto do metryki wybranych Pańskich są wpisani².

Ten parenetyczny aspekt kazania nie będzie nas tutaj dalej szczególnie zajmował, skoncentrujemy się raczej na pewnych właściwościach samej techniki kaznodziejskiej Birkowskiego, ściśle związanych z zakładanym przez niego rodzajem audytorium czy szerzej: z gustami i przyzwyczajeniami epoki, w której tworzył. Mamy tutaj niewątpliwie do czynienia z typem kazania „uczonego”, przeznaczonego dla publiczności zdolnej należycie docenić wartość mniej lub bardziej wyrafinowanych konceptów, którymi posłużył się autor, ale także jego rozległą erudycję i umiejętność przywoływania w stosownym momencie rozmaitych fragmentów zaczerpniętych, oczywiście, przede wszystkim z Biblii i z dzieł rozlicznych autorów kościelnych, ale również z utworów starożytnych i nowszych poetów oraz prozaików: mówców, historyków, niekiedy zaś - co z punktu widzenia podjętych tutaj rozważań szczególnie istotne - lekarzy czy też uczonych przyrodników ${ }^{3}$.

To manifestowanie przez Birkowskiego przy każdej nadarzającej się okazji swojego erudycyjnego przygotowania było zgodne $\mathrm{z}$ dość powszechną w jego czasach praktyką. Polski dominikanin dysponował bez wątpienia gruntownym wykształceniem, z czego jednak bynajmniej nie wynika, że wszystkie przywoływane przez siebie dzieła musiał znać z pierwszej ręki. Wręcz przeciwnie: podobnie jak inni współcześni mu kaznodzieje korzystał chętnie z niezwykle bogatej, narastającej od wieków literatury pomocniczej, na którą składały się rozmaite dawne i nowe kompendia gromadzące przydatną do układania kazań wiedzę, wydobytą z prac duchownych i świeckich autorów, uporządkowaną i opatrzoną rozbudowanymi indeksami, ułatwiającymi w razie potrzeby szybkie znalezienie potrzebnych informacji. Wiązał się z tym zresztą pośrednio również bardzo specyficzny stosunek do kwestii własności autorskiej. Pod koniec w. XVII w przedmowie do swojego zbioru kazań ksiądz Bazyli Rychlewicz pisał np.:

I nie poczytam sobie za nagany godną kradzież owych, którzy z cudzych ksiąg i skryptów rzeczy godne pamięci, rzeczy dowcipne, nowe, osobliwe i modne z swoją materyją łączą i zdobią, albowiem perły z morza na brzegi wyrzucone tego są, który je wprzód znajdzie i osiągnie. Żaden autor z starych jako naszego wieku, lub świecki, lub duchowny, i jeden nie znalazł się taki, który by z własnego kruszca i (chcę mówić) góry swego dowcipu miał tak wielkie, obfite, tak wielu godnych ksiąg wykopać i wybrać bogactwa i skarby. Poczciwą, chwalebną autorowi każdemu wydającemu in lucem opera godzi się jako panu bawić kradzieżą ${ }^{4}$.

2 F. B irk o w s ki, Stefan Chmielecki, abo nagrobek [...] pamięcia pogrzebna wystawiony. Warszawa 1632, k. A2. Przytoczony tutaj przez Birkowskiego łaciński werset, często zresztą powtarzany przez różnych dawnych autorów, pochodzi z Wojny domowej L u k a n a (X 407).

O roli konceptów w barokowym kaznodziejstwie pisał ostatnio przede wszystkim W. P a w1 a k (Koncept w polskich kazaniach barokowych. Lublin 2005).

4 B. R y c hl e w i c z, Kazania poczawszy od Adwentu do Wielkiejnocy inclusive, na niedziele, święta Zbawiciela i Jego Matki. Kraków 1698, k. C2v. Cyt. za: W. P a w 1 a k, „, O pewnym sposobie naszych literatów, że przy niewielkim czytaniu moga się łatwo wielkimi erudytami pokazać”. Kompendia jako źródło erudycji humanistycznej. W zb.: Staropolskie kompendia wiedzy. Red. I. Dacka-Górzyńska, J. Partyka. Warszawa 2009, s. 55. 
Bardzo charakterystyczne i zgodne z duchem epoki jest zresztą samo zawarte w przytoczonym fragmencie zestawienie różnych rodzajów materii czerpanej przez uczonego kaznodzieję z dzieł jego poprzedników. Składają się na nią „rzeczy godne pamięci, [...] dowcipne, nowe, osobliwe i modne”. Aby sprostać oczekiwaniom nieco bardziej wymagających słuchaczy, musiał taki kaznodzieja często sięgać nie tylko do Biblii oraz ksiąg dawnych i nowszych teologów, lecz również do prac autorów świeckich, reprezentujących rozmaite dziedziny wiedzy. Epatował zatem odbiorców wielkim nagromadzeniem faktów kuriozalnych i egzotycznych, z samej swojej natury szczególnie dobrze nadających się do konstruowania wyszukanych konceptów. Eksponowane miejsce zajmowały wśród nich liczne informacje przyrodnicze wydobywane zwykle przede wszystkim z Historii naturalnej Pliniusza Starszego oraz z dzieł innych pisarzy starożytnych, ale często także z ogłoszonych właśnie ksiąg XVI- i XVII-wiecznych naturalistów, encyklopedystów i autorów relacji podróżniczych. Ulegając tej dość powszechnej w jego czasach modzie, zwracał się tedy również ksiądz Birkowski do swojego audytorium, a może raczej tylko po prostu do swoich czytelników:

Widzieliście, jaką mocną ręką z pogańskich rąk jako z Egiptu niejakiego wyzwolił Bóg chrześcijany swoje, chrześcijany, których męstwo podobne jest nosorożcowi, rhinoceroti. Osman cesarz turecki, który niedawno pod Chocimiem był, miał słonie z sobą, sam słoniem bestyjalnym będąc. Przeciwko słoniowi Bóg posłał nosorożca, lud polski, którego męstwo było podobne nosorożcowi. Plinius lib. 8. c. 20. opisuje rynocerota i mówi, że jest barwy bukszpanowej, ma róg, który od nosa pochodzi nie prosto, ale krzywo i na ukos i stąd nazwany jest rynoceros, od rin, to jest nos, i keros, to jest róg, którym on dziwnie mężny jest i wojuje z elefantem, któremu w wysokości niemal jest równy, ale goleni krótszych. Obostrza róg o skałę i tak się na wojnę gotuje, w której do brzucha elefantowego zmierza, o którym wie, że nasłabszy; ten gdy zbodzie, zaraz zmoże elefanta. I tak Emanuel król luzytański w roku 1515 w Lisibonie znakomity widok sobie uczynił, spuściwszy elefanta z rynocerotem, na którym przegrał elefant. Zaczym rynocerot symbolum jest męstwa, a zatym Boga, który jest namężniejszym ${ }^{5}$.

Ta konkluzja, oczywiście, sama w sobie może nasuwać rozmaite wątpliwości natury logicznej, ale stoi za nią wypracowany przez wieki w kulturze chrześcijańskiej specyficzny model postępowania z materią symboliczną ${ }^{6}$. Rozumowanie Birkowskiego nie wytrzymałoby z pewnością próby logicznej analizy, ale przeciętny XVII-wieczny słuchacz lub czytelnik najprawdopodobniej w ogóle nie zwracał na to uwagi. Czytelnik taki żył bowiem na co dzień w świecie pełnym przeróżnych barokowych konceptów, a zatem konstrukcji myślowych, które odwoływały się z reguły do własnej, bardzo specyficznej, niekiedy wręcz kuriozalnej, logiki.

5 Birkowski, op. cit., s. 8 .

6 W ramach owej tradycji o tym, że za symbol Stwórcy zostaje uznane jakieś zwierzę, roślina czy też kamień, nader często przesądza jedna tylko właściwość, podczas gdy inne niekiedy w znacznie mniejszym stopniu predestynują dany obiekt do tej szczególnej roli. Nosorożec np. powszechnie uchodził dawniej za zwierzę wyjątkowo szpetne, nikt jednak w XVII stuleciu, idąc śladem Birkowskiego, nie zdecydowałby się chyba uznać go w związku z tym za symbol Boga, „który jest najszpetniejszy", lecz wręcz przeciwnie - skłonny byłby raczej widzieć w zwierzęciu symboliczne wyobrażenie szatana. Ten bardzo specyficzny sposób traktowania poszczególnych symboli otwierał drogę do systematycznego pojawiania się paralelnych interpretacji in bono oraz in malo w odniesieniu do tej samej istoty. Takiej powszechnie stosowanej egzegetycznej praktyce patronował przede wszystkim św. Augustyn, który pisał o tych kwestiach zwłaszcza w trzeciej księdze traktatu De doctrina christiana. Zob. m.in. J. S o k ols k i, Stownik barokowej symboliki natury. Tom wstępny: Barokowa księga natury. Wrocław 2000, s. 55-57. 
Odsyłając odbiorcę do wielkiej encyklopedii Pliniusza Starszego, postępuje Birkowski zgodnie z dość rozpowszechnioną w jego czasach praktyką, mimo bowiem pojawienia się nowych dzieł zoologicznych, z monumentalną wielotomową pracą Konrada Gessnera na czele, w pierwszej połowie XVII w. Historia naturalna wciąż pozostawała głównym, a niekiedy wręcz jedynym punktem odniesienia dla autorów, którzy w swoich pracach z jakichś powodów zdecydowali się pisać o rozmaitych egzotycznych zwierzętach, roślinach czy minerałach. Jest jednak bardzo charakterystyczne i nieco dziwne, że polski kaznodzieja twierdzi tutaj stanowczo, iż Pliniusz przekazał nam na temat nosorożca również pewne informacje, których w przywołanym fragmencie jego dzieła bynajmniej nie znajdujemy. W rzeczywistości czytamy tam tylko (Nat. hist., VIII, 76) dość zwięzłą i - co za tym idzie - nie zawierającą zbyt wielu szczegółów wzmiankę o jednorogim nosorożcu, którego w Rzymie po raz pierwszy ujrzano rzekomo w czasie słynnych igrzysk urządzonych dla ludu w 55 r. p.n.e. przez Pompejusza Wielkiego:

Jest to drugie zwierzę będące naturalnym nieprzyjacielem słonia. Ostrząc swój róg o skałę gotuje się do boju, walcząc zaś, atakuje przede wszystkim brzuch, o którym wie, że jest najwrażliwszy. Dorównuje słoniowi długością, ma jednak dużo krótsze nogi. Jest bukszpanowej [tj. bladożółtej] barwy ${ }^{7}$.

Brak tutaj, jak nietrudno zauważyć, podanych przez Birkowskiego informacji o ukośnym ustawieniu rogu, a także o greckim pochodzeniu i znaczeniu nazwy zwierzęcia. Sam opis Pliniusza, zdaniem przynajmniej części badaczy, wskazywałby raczej na nosorożca indyjskiego (Rhinoceros indicus unicornis), ponieważ ten, w przeciwieństwie do obu gatunków afrykańskich (nosorożec czarny: Dioceros bicornis, oraz nosorożec biały: Ceratherium simum), ma tylko jeden róg ${ }^{8}$, chociaż, z drugiej strony, William Gowers w swoim czasie dowodził, iż wszystkie starożytne informacje (w tym również przytoczony tutaj fragment dzieła Pliniusza) na temat osobników sprowadzanych do Rzymu dotyczą białych nosorożców, które pochodzić miały z terenów dzisiejszego Sudanu, położonych na zachodnim brzegu Białego Nilu9 . O tym, że również indyjskie nosorożce docierały niekiedy w starożytności do Italii, świadczyć może jednak choćby pompejański relief przechowywany dzisiaj w muzeum archeologicznym w Neapolu, wyobrażający bez wątpienia jakiegoś przedstawiciela tego właśnie gatunku ${ }^{10}$.

${ }^{7}$ Przekład mój - J. S. (podobnie dalej, jeśli nie zaznaczyłem tego inaczej). Pierwszym naturalnym nieprzyjacielem słonia był, jak wiadomo, smok lub gigantyczny wąż, o czym Pliniusz wspomina jednak w innym miejscu. Należy tutaj dodać, że odmienna od stosowanej powszechnie dzisiaj lokalizacja fragmentu w dziele Pliniusza podana przez Birkowskiego była zgodna z podziałem księgi VIII na rozdziały, pojawiającym się zwykle w ówczesnych edycjach. s. 212

${ }^{8}$ Zob. np. H. L e it n e r, Zoologische Terminologie beim Älteren Plinius. Hildesheim 1972,

9 Zob. W. G o w e r s, The Classical Rhinoceros. „Antiquity” t. 24, nr 94 (1950). Błąd Pliniusza, który twierdził, że nosorożec sprowadzony do Rzymu przez Pompejusza miał tylko jeden róg, mógł po prostu wynikać z faktu, iż w przypadku białych nosorożców tylny róg jest niekiedy tak mały, że niezmiernie trudno go w ogóle zauważyć. Ocenę wartości tych argumentów wypada pozostawić specjalistom. Zob. też na ten temat J. M. C. To y n b e e, Animals in Roman Life and Art. Baltimore, Mar., 1996, s. 126.

${ }_{10}$ Reprodukcję owego nosorożca zamieszcza O. K e 11 e r w pracy Die antike Tierwelt (t. 1. Leipzig 1909, s. 387). G. J e $\mathrm{n} n$ i s o n (Animals for Show and Pleasure in Ancient Rome. Philadelphia 2005, s. 35) zwraca uwagę również na to, że nosorożce indyjskie zwykle dużo łatwiej przysto- 
Z naszego punktu widzenia są to zresztą wszystko kwestie zupełnie drugorzędne, ponieważ Birkowski oczywiście nie zdawał sobie w ogóle sprawy z faktu, iż w przyrodzie występuje kilka różnych gatunków nosorożców i że sprowadzony na początku XVI w. do Europy przez Portugalczyków okaz reprezentował jednak najprawdopodobniej inny gatunek niż ten opisany niegdyś przez Pliniusza. Słonie przybyłe wraz z armią Osmana mógł zapewne sam widzieć (choćby tylko z daleka) w obozie pod Chocimiem, nosorożca z pewnością nie oglądał nigdy. Chyba jedynym wcześniejszym polskim autorem, który twierdził, że go widział podczas wyprawy poselskiej do Turcji, był Maciej Stryjkowski ${ }^{11}$. Nosorożec portugalskiego króla Manuela I został uwieczniony na słynnej (często i dzisiaj reprodukowanej) rycinie przez samego Albrechta Dürera, który jednak opierał się tylko na opisie i dostarczonym mu przy jakiejś okazji niezbyt dokładnym amatorskim szkicu. Ten drzeworyt wielkiego artysty był następnie nieustannie kopiowany, trafiał też do różnych prac przyrodniczych, ze wspomnianym już tutaj dziełem Konrada Gessnera na czele ${ }^{12}$. Jeżeli zatem polski kaznodzieja miał jakiekolwiek wyobrażenie o wyglądzie niezmiernie przecież rzadko widywanego w Europie zwierzęcia, to czerpał je najprawdopodobniej właśnie z tego rodzaju ilustracji ${ }^{13}$. Mógł jednak znać również inną rycinę, którą w krótkim dziełku Discours da la licorne zamieścił sławny XVI-wieczny francuski medyk, Ambroise Paré ${ }^{14}$. Przedstawiała ona właśnie opisaną przez Pliniusza scenę walki nosorożca ze słoniem.

Greccy i rzymscy autorzy na ogół zgodnie utrzymywali, że nosorożec jest śmiertelnym wrogiem słonia, i Pliniusz powtarzał tylko opinię wydobytą z prac poprzedników. Wspomniany przez Birkowskiego król Manuel próbował więc jedynie sprawdzić wiarygodność owych książkowych informacji odziedziczonych po starożytności. W epoce renesansu zaczęto zresztą sięgać również do greckich traktatów zoologicznych. Znano już zatem dobrze dzieło Eliana o zwierzętach, w którym można było przeczytać opinię nieco odmienną od przedstawionej przez rzymskiego encyklopedystę. Według greckiego autora zaatakowane przez noso-

sowują się do życia w niewoli niż ich afrykańscy kuzyni, co według niego czyni fakt ich pojawiania się w rzymskich zwierzyńcach i na arenach cyrków bardziej prawdopodobnym.

${ }_{11}$ M. Stryj k ow s ki, O poczatkach, wywodach, dzielnościach, sprawach rycerskich i domowych sławnego narodu litewskiego, żemojdzkiego i ruskiego, przedtym nigdy od żadnego nie kuszone ani opisane, z natchnienia Bożego a uprzejmie pilnego doświadczenia. Oprac. J. Radziszewska. Warszawa 1978, s. 240. Ukazując przerażającą postać pewnego olbrzymiego Tatarzyna, autor stwierdza m.in., iż miał on „nos krzywy rynocerów” i w marginalnej notce tłumaczy: „Rynoceres jest źwierzę albo bestyja szpetna, łuskami jak talerzami obrosła w Afryce, a na nosie ma róg krzywy. Jam go w Konstantynopolu widział 1575". Nosorożec ten miał być rzekomo darem przesłanym sułtanowi Amuratowi przez legendarnego Księdza Jana (Popiana), o czym M. S try j k o w s k i wspomina również przelotnie w swojej Kronice polskiej, litewskiej, żmudzkiej i wszystkiej Rusi (Wyd. M. M a li n o w s ki. T. 1. Warszawa 1846, s. 13), przede wszystkim zaś w poprzedzającym ją obszernym autobiograficznym wierszu Maciej Stryjkowski Osostevicius sam o sobie i przygodach swoich $w$ zwiedzaniu rozmaitych krain świata (ibidem, s. XVII).

${ }_{12}$ C. G e s n e r i Historiae animalium lib. I. de quadrupedibus viviparis. Tiguri 1551, s. 953 (cały fragment poświęcony nosorożcom mieści się tutaj na s. 952-955).

${ }_{13} \mathrm{O}$ tradycji plastycznych przedstawień nosorożców w Europie wczesnonowożytnej pisał T. H. Cl a r k e (The Rhinoceros: From Dürer to Stubbs, 1515-1799. London 1986).

${ }^{14}$ A. P a r é, Des Monsters et prodiges. Précédé de Des animaux et de l'excellence de l'homme et suivi par Discours de la licorne. Paris 2003, s. 258. 
rożca słonie umiały sobie bowiem najczęściej poradzić z napastnikiem, jeśli tylko uniknęły zadanego sobie podstępem uderzenia w brzuch:

Opisywać wygląd nosorożca - to temat aż nadto oklepany! Wielu Hellenów i Rzymian zna i widziało to zwierzę. Nie zawadzi jednak opowiedzieć o jego trybie życia.

$\mathrm{Na}$ końcu nosa rośnie mu róg - stąd nazwa. Szpic rogu jest nadzwyczaj wyostrzony i twardy, jakby był z żelaza. Nosorożec ostrzy go o skałę i nie zawaha się wyzwać do walki nawet słonia, chociaż nie dorównuje wzrostem ani siłą tej potężnej bestii. Cóż więc robi? Wali się na ziemię u nóg słonia i rogiem rozdziera mu brzuch od spodu. Krew bucha, a po chwili zwierzę pada martwe. Nosorożec walczy ze słoniem o tereny wypasu i nierzadko zdarza się widok słonia, który zginął w takim starciu. Jeśli jednak nosorożec nie dość szybko ugodzi przeciwnika i nie zdąży uciec, słoń może go sobą przygnieść. Wtedy opasuje go trąbą, trzyma mocno w uścisku, wlecze ku sobie, potem powala i siecze na kawałki ciosami jak toporem. Bo chociaż nosorożec pokryty jest tak twardą skórą, że strzały jej nie przebiją, mimo wszystko mocarna siła słonia jest nie do pokonania ${ }^{15}$.

Czy Birkowski znał ten fragment dzieła Eliana, trudno powiedzieć. W swoim kazaniu powołuje się na wiele różnych źródeł dawnych i nowszych, ale do Eliana odsyła czytelnika dopiero w momencie, kiedy zaczyna pisać o jednorożcu ${ }^{16}$. Obraz zwycięskiego słonia nie był mu jednak po prostu do niczego potrzebny, co więcej, kłóciłby się z pewnością z intencjami całego autorskiego wywodu, a także z symbolicznym porządkiem organizującym świat przedstawiony utworu. Jeżeli bowiem nosorożec oznacza męstwo, a pośrednio samego Boga, ,który jest namężniejszym”, to jakakolwiek jego porażka w walce ze słoniem, będącym figurą ,,bestyjalnego" Osmana ${ }^{17}$ i niezliczonych innych nieprzyjaciół chrześcijańskiego świata (pośrednio

${ }^{15}$ E 1 i a n, O właściwościach zwierząt (wybór). Przeł. A. M. K o m o r n i c k a. Warszawa 2005, s. 276 (ks. XVII, rozdz. 44).

${ }_{16} \mathrm{Z}$ tego faktu wcale nie musi jednak wynikać, że Birkowski rzeczywiście sam czytał traktat Eliana, ustęp o jednorożcu mógł przecież równie dobrze znaleźć w jakimś uczonym kompendium, z którego przygotowując swoje kazanie korzystał. Ciekawe jest bowiem to, że polski kaznodzieja odsyła $\mathrm{w}$ tym miejscu jednocześnie do dwóch różnych fragmentów dzieła Eliana: do rozdziału 20 księgi XVI, gdzie w rzeczywistości mowa jest o jednorożcu, którego grecki pisarz nazywa „kartazonos", ale także do przytoczonego tutaj wcześniej rozdziału księgi następnej, traktującego o nosorożcach.

17 Wprawdzie przymiotnik ,bestialni” znaczył oczywiście w XVII w. przede wszystkim: ‘nieludzki', 'zwierzęcy', jednak podkreślona tutaj przez Birkowskiego „bestyjalność” Osmana odnosi się, jak dużo na to wskazuje, raczej do jego szczególnych preferencji seksualnych. Gdzie indziej bowiem, umieszczając zmarłego już sułtana w piekle, polski dominikanin utrzymywał, iż trafił on tam m.in. dlatego, że za życia był „pełen z swoimi obrzydliwości sodomskich, cudzołożniczych” (F. B i r k o w s k i, Kazanie obozowe o Bogurodzicy. Przy tym Nagrobek Osmanowi, cesarzowi tureckiemu [...]. Kraków 1623, s. 37). Trudno dzisiaj powiedzieć, dlaczego to właśnie słoń stał się symbolem tych godnych potępienia rzekomych skłonności tureckiego władcy, chociaż współczesne badania wykazują np., że homoseksualne zachowania wśród trzymanych w niewoli słoni indyjskich dotyczą aż ok. 45\% całej populacji. Zob. B. B a g e m i h 1, Animal Homosexualism and Natural Diversity. New York 1999, s. 427-430. Birkowski nie mógł, oczywiście, znać tych ustaleń, ale mógł przeczytać podobnego typu rewelacje w jakichś ówczesnych relacjach podróżniczych. Niestety, dotąd nie udało mi się trafić w nich na fragment traktujący o tego rodzaju zachowaniach słoni. Warto wszakże przy okazji zauważyć, że zwierzętom tym dość powszechnie przypisywano dawniej np. dziwną skłonność do niewiast, co w gruncie rzeczy należy przecież uznać również za pewien rodzaj transgresywnego, niezgodnego z porządkiem natury, zachowania. Pisałem o tym kiedyś nieco szerzej w artykule Elephantographia curiosa, czyli porozmawiajmy o stoniach (w zb.: Różnorodność form narracji w literaturze dawnej. Red. M. Rowińska-Szczepaniak, J. Zagożdżon. Opole 2006). Prawdopodobne jest jednak także inne wyjaśnienie. Czytając w encyklopedii Pliniusza (Nat. hist., VIII, 1) rozdział poświęcony prezentacji słonia, Birkowski już na wstępie mógł znaleźć w nim charaktery- 
zaś szatana, któremu służą), nie jest po prostu możliwa. Eksperyment przeprowadzony na początku w. XVI w Lizbonie na polecenie portugalskiego monarchy stanowił zresztą dla polskiego kaznodziei wystarczający i ostateczny dowód W sprawie ${ }^{18}$.

Nosorożec jest zatem symbolem samego Stwórcy - przede wszystkim ze względu na swoje niezwykłe męstwo. Nie daje się nikomu okiełzać, potrafi też pokonać najpotężniejszego nawet nieprzyjaciela. Dla księdza Birkowskiego nie jest to wszakże jedyny i wystarczający powód. Dlatego pisze:

Znowu nosorożec jest znakiem gniewu nierychłego, ale strasznego. Bo on potrzebuje wielkiego rozgniewania, ale skoro się gniewać pocznie, jest barzo okrutny: takowym jest Bóg, który leniwe karanie ciężkością nagradza. Stąd przysłowie: Dii laneos pedes habent. Bóg chodzi na wełnianych nogach, sed ferreas manus, ale ma ręce żelazne. Przeto pierwszy, który na teatrum wprowadził rynocerota przeciwko bykowi i niedźwiedziowi, Domicyjan cesarz, in dedicatione amphitheatri, kazał monetę bić z obrazem nosorożca, aby dał znać, że podobnym jest tej bestyjej. Naprzód, że wielkie ma serce i królewskie męstwo przy nim jest. Po wtóre, że leniwym jest do gniewu, ale jako się rozgniewa - nieubłaganym. Wyraził to dwiema epigramaty Marcyjalis, który u Domicyjana był w wielkim kochaniu ${ }^{19}$.

Oba te epigramaty Marcjalisa przytacza Birkowski dalej, opatrując je dodatkowo polskimi prozaicznymi tłumaczeniami ${ }^{20}$. Nosorożec nie walczy w nich wprawdzie ze słoniem, ale obraz bestii ciskającej w powietrze bykiem, a następnie niedź-

stykę czyniącą to stworzenie wyjątkowo „ludzkim”: „Największy, a i pod względem zdolności umysłu człowiekowi najbliższy, jest słoń. Rozumieją bowiem słonie język otoczenia, posłuch dają rozkazom, pamiętają o powinnościach, których się nauczyły, czują także rozkosz, jakiej dostarczają miłość i sława, nadto zaś przejawiają rzadko u ludzi spotykaną uczciwość, roztropność i poczucie sprawiedliwości. Otaczają też czcią gwiazdy, słońce i księżyc. Opowiadają niektórzy, iż w mauretańskich lasach stada słoni przy świetle nowego księżyca nad rzeką zwaną Amilos schodzą się i tu dokonują uroczystego oczyszczającego aktu przez polewanie siebie wodą, a kiedy już powitają księżyc w ten sposób, powracają do lasów, te z młodych, które są znużone, dźwigając przed sobą". Jeżeli Osman był, zdaniem Birkowskiego, ,słoniem bestyjalnym”, oznaczać to mogło w konsekwencji odmówienie owemu zwierzęciu wszystkich tych chwalebnych cech, o których z takim podziwem pisał przed wiekami Pliniusz.

${ }_{18}$ Nosorożec, którego król Manuel otrzymał od gubernatora Indii w r. 1515, trafił do królewskiego zwierzyńca w Ribeirze. Jego walka z młodym niedoświadczonym słoniem zakończyła się ucieczką tego ostatniego (słoń przestraszył się jednak bardziej hałasującego tłumu widzów niż groźnie wyglądającego przeciwnika). Samego nosorożca król zdecydował się ostatecznie podarować papieżowi Leonowi X, wielkiemu amatorowi tego rodzaju egzotycznych osobliwości. Niestety, statek, na którym nosorożca wysłano do Italii, zatonął u liguryjskich wybrzeży nieopodal Genui i spętane łańcuchami zwierzę po prostu utonęło. Zob. m.in. S. A. B e d d i n i, The Papal Pachyderms. „Proceedings of the American Philosophical Society” 125 (1981), s. 80-81.

19 B i r k o w s k i, Stefan Chmielecki [...], s. 8-9. Przywołana tutaj przez Birkowskiego łacińska sentencja, której w swoim tłumaczeniu spróbował on przy okazji nadać bardziej monoteistyczny charakter, znana była w XVII w. dość powszechnie i często przez różnych autorów wykorzystywana jako uczony ekwiwalent powiedzeń w rodzaju „Pan Bóg nierychliwy, ale sprawiedliwy”. Jej pierwszy człon miał szacowny starożytny rodowód, w różnych formach pojawiał się m.in. u Petroniusza i u Makrobiusza, przede wszystkim zaś znajdujemy go w Adagiach Erazma z Rotterdamu. Drugi segment był już niewątpliwie późniejszym uzupełnieniem.

${ }^{20}$ Ibidem, s. 9. O wspomnianych tutaj dwóch epigramatach wchodzących w skład Liber de spectaculis Marcjalisa pisał ostatnio T. V. B u t tre y w pracy Domitian, Rhinoceros, and the Date of Martial's Liber de spectaculis (,Journal of Roman Studies” $97\langle 2007\rangle$ ). W artykule tym można także znaleźć m.in. fotografię owej wybitej na polecenie Domicjana niewielkiej miedzianej monety - upamiętniającej inaugurację amfiteatru - o której czytamy u Birkowskiego. Zawierała ona zresztą, 
wiedziem - bardziej dla odbiorców kazania swojskimi - musiał chyba dość mocno przemawiać do ich wyobraźni. Fragment ten może być zapewne interesujący dla badaczy dziejów polskiej recepcji Marcjalisa (jeśli oczywiście są tacy), z punktu widzenia podjętych tutaj rozważań znacznie istotniejszy jest jednak ustęp kolejny:

Tenże Plinius lib. 8. c. 21. opisuje jednorożca i mówi: „Monoceros jest okrutne źwierzę, podobne koniowi we wszytkim oprócz głowy, która podobna jest jeleniowi, i nóg, które elefantowi, ogona, który wieprzowi; ryk jego ciężki, jeden ma róg w pół czoła na dwa łokcie długi; powiadają, iż tego źwierza żywcem nikt nie pojma". Toż pisze Aelianus lib. 16. de animal. c. 20. et lib. 17. c. 44, który czyni jednorożca na grzywie i na sierci czarnym, prędkim w nogach, róg mu daje czarny, łaskawość przeciw innym bestyjom, srogość przeciw swoim. Tego Pierius in hierogliphico Rhinocerotis halicornem zowie i rozumie tegoż, którego Septuag. monocerotem nazwali, a Vulgat. unicornem. Bo żydowskie słowo reem i jednorożca, i nosorożca znaczy ${ }^{21}$.

Dzisiaj dobrze wiemy, że żydowskie słowo „re'em” nie oznacza z pewnością ani jednorożca, ani nosorożca ${ }^{22}$. Może to być dziki bawół górski lub oryks; uczeni długo jeszcze będą się prawdopodobnie spierać na ten temat, szukając odpowiedzi w różnych miejscach, ale bez wątpienia nie w kazaniu Birkowskiego.

Bardziej interesująca jest jednak pewna manipulacja, której dopuszcza się tutaj dominikanin. Zestawia ze sobą dwa fragmenty dzieł starożytnych autorów traktujące o jednorożcu. Obaj oni jednak najwyraźniej uważali, że jednorożec i nosorożec to dwa zupełnie różne gatunki egzotycznych zwierząt, ponieważ obaj omawiają je osobno. Dla obu też nosorożec jest zwierzęciem dobrze znanym (Elian nawet pisanie o nim uznaje za zajęcie dość banalne), podczas gdy jednorożec jest istotą, o której tylko czytali oni w dziełach różnych dawniejszych autorów omawiających osobliwości Indii. I nie ma tu większego znaczenia fakt, że dzisiaj badacze skłonni są przyjmować, iż monoceros Pliniusza to w rzeczywistości nosorożec indyjski, którego wyobrażenie, zanim do niego dotarło, uległo po prostu daleko posuniętej deformacji ${ }^{23}$. Dla Birkowskiego wystarczającym powodem, żeby oba gatunki zwierząt ze sobą w pewnym sensie (chociaż nie całkowicie) utożsamić, jest sam fakt, iż hebrajskie słowo „re'em" miało rzekomo określać zarówno nosorożca, jak i jednorożca.

Cała ta operacja odbywa się na oczach czytelnika, kaznodzieja niczego przed nim nie ukrywa: jednorożec i nosorożec to dwa różne stworzenia, ale oznaczają to samo, ponieważ natchnieni autorzy biblijni, mówiąc o nich, używali identycznej nazwy. Taka argumentacja jest dla nas z pewnością mocno podejrzana, w XVII stuleciu jednak mogła $\mathrm{z}$ wielu powodów liczyć na zrozumienie i akceptację. Zgodnie z dawną tradycją, wywodzącą się bezpośrednio z Księgi Rodzaju $(1,19)$ tym, kto nadał zwierzętom ich nazwy, był praojciec Adam ${ }^{24}$. Stanowiło to swoisty symboliczny ekwiwalent brania świata we władanie. Obdarzony niezwykłą, po-

na co wszystko wskazuje, pewne propagandowe przesłanie, dość zbliżone do tego, które przedstawił polski kaznodzieja.

${ }^{21}$ B i rk o w s k i, Stefan Chmielecki [...], s. 9-10.

${ }_{22}$ Zob. m.in. K. M orta, Biblijny re'em. „Kaliskie Studia Teologiczne” 1 (2002).

${ }_{23}$ Zob. F. M a s p e r o, Bestiario antico. Gli animali-simbolo e il loro significato nell 'immaginario dei popoli antichi. Casale Monferrato 1997, s. 286.

${ }_{24}$ Plastyczne przedstawienia tej sceny często zdobią np. rękopisy średniowiecznych bestiariuszy, o czym pisała w swoim czasie X. M u r a t o v a (Adam donne leurs noms aux animaux. „Studi Medievali" $18\langle 1977\rangle$ ). 
chodzącą bezpośrednio od samego Stwórcy mądrością, dysponował Adam także, jak utrzymywali później, w miarę zgodnie, dawni żydowscy i chrześcijańscy komentatorzy, wrodzoną niejako znajomością prawdziwej natury wszystkich stworzeń, co sprawiało, że w jego przypadku nadawanie imion żywym istotom nie było bynajmniej aktem arbitralnym. Pozostaje jednak pytanie o język, którym posługiwał się wówczas Adam. Niezależnie od pojawiających się niekiedy odmiennych koncepcji (w XVII w. też ich nie brakowało) dominowało wśród chrześcijańskich pisarzy, występujące już w dziełach św. Augustyna czy Izydora z Sewilli, przeświadczenie bardzo dobitnie wyrażone przez autora jednego z XIII-wiecznych łacińskich bestiariuszy: „Adam nadał imiona nie po grecku ani po łacinie, ani też w językach barbarzyńskich ludów, lecz w tym języku, który był wspólny wszystkim ludziom przed potopem, a który nazywany jest hebrajskim" 25 .

Jeżeli tedy natchnieni biblijni autorzy posługiwali się wspólnym słowem na określenie jednorożca i nosorożca, to czynili tak nie dlatego, że nie wiedzieli, jak nazwać pojawiające się w świętym tekście stworzenia, lecz dlatego, że w Raju Ziemskim otrzymały one to samo imię. Adam, dysponujący pochodzącą od Boga szczególną wiedzą dotyczącą ich natury, z sobie tylko znanych powodów uznał taki onomastyczny zabieg za niezbędny. Nastąpiło to bez wątpienia z przyzwoleniem Stwórcy, który był zresztą jednocześnie autorem obu wielkich ksiąg: księgi natury i Biblii. Ksiądz Birkowski mógł być zatem przekonany, że pomiędzy porządkiem stworzonego świata a porządkiem Pisma pojawiają się tylko niekiedy pozorne sprzeczności, których rozwikłanie ostatecznie zależy wyłącznie od wiedzy i umiejętności interpretatora.

Całe przedstawione tutaj rozumowanie miało, oczywiście, jeden szczególnie słaby punkt: polskiemu dominikaninowi, podobnie jak wielu jego współczesnym, nie przyszło po prostu do głowy, że o ile Stwórca czuwał nad samymi natchnionymi autorami świętych ksiąg, o tyle najwyraźniej nie zawsze wspierał w wystarczającym stopniu ich łacińskich i greckich tłumaczy, i że w związku z tym cały problem nie wynikał z wieloznaczności hebrajskiego słowa „re'em”, lecz z trudności, jakie greccy i łacińscy translatorzy Pisma mieli ze znalezieniem stosownych ekwiwalentów w swoich językach.

Pozostawiając tę kwestię na boku, spróbujmy jednak jeszcze spojrzeć na tryb postępowania Birkowskiego z nieco innej perspektywy, której przyjęcie sprawi, że wyrażone $\mathrm{w}$ poprzednim akapicie obiekcje staną się $\mathrm{w}$ gruncie rzeczy mało istotne. Godzi się bowiem zauważyć, że autor kazania nie występuje tutaj jako komentator Pisma ani przyrodnik. Konstruuje on konceptystyczny tekst zbudowany z tradycyjnych elementów. W związku z tym może dość swobodnie wędrować pomiędzy trzema opisanymi kiedyś przez Dana Sperbera ${ }^{26}$ podstawowymi poziomami wiedzy: wiedzą semantyczną, encyklopedyczną i symboliczną, przy czym ta ostatnia ma w kazaniu znaczenie najważniejsze. Wspiera się ona, oczywiście, przede wszystkim na wiedzy encyklopedycznej, która jednak podlega procesom ciągłej weryfikacji (wśród przytoczonych przez Sperbera zdań reprezentujących ten rodzaj wiedzy znajdujemy, $n b$. również zwięzłe, twierdzenie: „Jednorożce nie

${ }^{25}$ Cyt. za: P. C. A $1 \mathrm{~m}$ o n d, Adam and Eve in Seventeenth-Century Thought. Cambridge 1999, s. 129.

${ }^{26}$ D. S p e r b e r, Symbolizm na nowo przemyślany. Przeł. B. B a r a n. Kraków 2006, s. 83-106. 
istnieją"), natomiast z wiedzą symboliczną rzecz ma się zgoła inaczej. Jednorożec nie musi wcale istnieć, żeby nadal pozostać np. łatwo rozpoznawalnym symbolem chrystologicznym. O ile bowiem wiedza semantyczna jest wiedzą o słowach, wiedza zaś encyklopedyczna wiedzą o rzeczach, o tyle wiedza symboliczna to, zgodnie z formułą Sperbera, wiedza o pamięci słów i rzeczy. Dodajmy tutaj przy okazji: również o pamięci słów źle rozumianych i rzeczy nieistniejących lub istniejących inaczej; pamięci np. o tym, że hebrajskie słowo „re'em” oznacza jednocześnie indyjskiego nosorożca i baśniowego jednorożca.

Birkowski dysponował, jak można z dużą dozą prawdopodobieństwa przyjąć, dość rozległą wiedzą na temat jednorożców, czego świadectwo daje w dalszej części kazania, odsyłając do dzieł rozmaitych dawnych autorów kościelnych, takich jak komentujący rozdział 39 Księgi Hioba Grzegorz Wielki, ponadto zaś Izydor z Sewilli, Rupert z Deutz czy wreszcie Albert Wielki, z jego monumentalnym traktatem De animalibus, swoistą summą zoologicznej wiedzy wieków średnich. Birkowski nie wskazuje w tym przypadku konkretnych miejsc, ale ostatecznie te i inne lektury skłaniają go do wygłoszenia kategorycznego stwierdzenia: „Historyja ta jest prawdziwa, barzo przystojnie jednorożec ten Chrystusa Pana znaczy" ${ }^{27}$. Nieco dalej powołuje się on jednak również na kilku pisarzy świeckich, takich jak Marco Polo (Marcus Polus Venetus), pojawiający się już nieco wcześniej w kazaniu Pierius Valerianus, czy wreszcie na poświęcone w całości jednorożcom osobne dziełko, którego autorem był „Andreas Bacci medicus”28. Cała ta pracowicie zgromadzona wiedza pozwala na ostateczne udowodnienie tezy, iż w planie symbolicznym jednorożec wpisuje się dokładnie w ramy, które nieco wcześniej kaznodzieja sam wytyczył, kreśląc (głównie na podstawie owego krótkiego fragmentu encyklopedii Pliniusza) figurę walecznego nosorożca. Ale jednocześnie Birkowski może też w końcu powrócić do głównego tematu swojego kazania, jakim jest pochwała równie walecznego kijowskiego wojewody. Pisze zatem:

Ten monocerot, jako się wyżej rzekło, Boga samego znaczy, znaczy i lud izraelski, a to, że jednego Boga chwalił i przeto od Niego siły wielkie brał cudowne barzo, gdy się ugania $\mathrm{z}$ nieprzyjaciołami swymi. A ja to imię i to męstwo monocerotowe Chmieleckiemu mojemu oddam, którego mile godzien dla mężnych dzieł swoich, które czynił. Pyta Joba świętego Bóg sam: „Czy będzie chciał nosorożec służyć tobie, czy się zabawi u żłobu twego? Czy go ty przywiążesz do pługu rzemieniem twoim? Czy on będzie przewracał ziemię dolin twoich za tobą?" Pytam ja Kantymira bezecnego: Jakoż chcesz Chmieleckiego wiązać i prowadzić do hordy, jakoś przedtym innym czynił? Nie wiesz tego, że się nie da wiązać tobie ten monocerot, który pierwej umarł, nim pęta na ręce jego i na nogi padły? ${ }^{29}$

Warto zauważyć, że jednorożec (,,monocerot”) i nosorożec występują już w tym fragmencie po prostu wymiennie jako nazwy tego samego stworzenia, co jest oczywiście zgodne z całą logiką dotychczasowego autorskiego wywodu. Ostatecz-

${ }^{27}$ B irk ow sk i, Stefan Chmielecki [...], s. 10.

28 A. B a c c i, Alicorno. Discorso [...] nel quale si tratta della natura dell'alicorno, et delle sue virtù eccellentissime. Fiorenza 1574. Birkowski mógł zresztą również korzystać z tłumaczenia łacińskiego: De monocerote seu unicornu, eiusque admirandis viribus et usu tractatus [...] a Wolfgango Gabelchover [...] latine redditus, cui ob argumenti similitudinem accessit de magna bestia ab antiquis alce, Germanis Eland vocata, eiusque ungule pro epilepsia et con similibus morbis abigendis viribus et usu [...]. Stutgardiae 1598.

${ }^{29}$ B i rk ow s k i, Stefan Chmielecki [...], s. 11. 
nie zatem Birkowski dopisuje do odziedziczonego zespołu symbolicznych znaczeń jednorożca vel nosorożca nowy przenośny sens i w ten sposób spełnia się podstawowa panegiryczna intencja całego utworu. Dzięki zauważonym przez autora kazania analogiom jednorożec, który do tej pory symbolizował albo Boga, albo Chrystusa, albo w końcu Naród Wybrany, staje się odtąd również symbolem zmarłego dwa lata wcześniej kijowskiego wojewody. Można by zatem przyjąć, że mamy tutaj do czynienia $\mathrm{z}$ arbitralną decyzją zręcznie żonglującego tradycyjnymi symbolami wybitnego kaznodziei i że sam Chmielecki tylko w poświęconym mu pochwalnym utworze stawał się na moment owym tak bardzo od wieków wychwalanym przez chrześcijańskich autorów jednorożcem. Wojewoda był nim jednak w pewnym sensie już od urodzenia i aż dziwne, że w całym tekście kazania nie znajdujemy na ten temat najmniejszej nawet wzmianki. Chmieleccy pieczętowali się bowiem, jak wiadomo, herbem Bończa, przedstawiającym (jakżeby inaczej) srebrnego jednorożca na błękitnym polu, w łacińskich źródłach występującym czasem jako „Rinocerus”, kiedy indziej zaś - „Unicornus”. W kazaniu Birkowskiego mamy zatem do czynienia $\mathrm{w}$ gruncie rzeczy z kunsztowną, bardzo rozbudowaną heraldyczną aluzją, dość czytelną zapewne dla współczesnych, dziś już jednak dużo słabiej rozpoznawalną.

Symbolem nosorożca-jednorożca posłużył się zresztą Birkowski przynajmniej raz jeszcze, w Kazaniu na dzień nawrócenia Pawła św. ${ }^{30}$ Jego tytułowy bohater, nieprzejednany dotąd prześladowca chrześcijan, doświadczając swojej cudownej przemiany w drodze do Damaszku, zostaje tutaj porównany właśnie do tego niezwykłego stworzenia. Jednorożec - zgodnie ze świadectwem Księgi Hioba, które Birkowski przytoczył również w kazaniu o Chmieleckim - nie daje się pojmać i ujarzmić nikomu. Dla Boga nie ma wszakże rzeczy niemożliwych. Wbrew pozorom takie odwrócenie dotychczasowego symbolicznego porządku nie było jednak dziełem inwencji polskiego kaznodziei - szedł on bowiem, nie przyznając się do tego, śladem św. Grzegorza Wielkiego, który w swoich Moraliach zaproponował m.in. podobną interpretację figury jednorożca.

\section{Abstract}

JACEK SOKOLSKI

(University of Wrocław)

\section{FATHER BIRKOWSKI'S RHINOCEROS, THAT IS BAROQUE PREACHER'S SYMBOLIC PLAYS WITH READER}

Stefan Chmielecki, a newly appointed voivode of Kiev, who gained fame for the most part during Turkish invasions, died in 1630. Two years later, a Dominican, Fabian Birkowski, prince Władysław's chaplain, published a thorough preachment dedicated to him in which, consistent with the then fashion, he used a number of peculiar pieces of information about rhinoceros extracted mainly from old works and newer nature books. Identifying the rhinoceros (to whom the preachment protagonist was compared) with mythological unicorn, Birkowski constructed a subtle heraldic allusion. Though in the preachment he made no remark about that, his readers for certain knew that the Chmielecki's used the Bończa coat of arms which showed a unicorn against a blue background.

${ }^{30}$ F. B i r k o w s k i, Kazania na niedziele i święta doroczne [...]. Na święta przedniejsze po dwojgu kazań. Teraz powtórnie wydane z przydaniem niektórych kazań i regestru dostatecznego. Kraków 1623, s. 152-153. 